\title{
Philosophical taxonomies of well-being
}

\section{Samuel Clark}

\section{Introduction}

The philosopher's question about well-being is 'what is it for someone's life as a whole to go best for her?'. This isn't the same question as 'what does she need if her life is to go best?' or 'what would help or harm her?'. The philosopher's question is about what well-being is rather than about what are its conditions or causes. Compare the difference between 'what is health?' and 'is smoking bad for your health?'. The question about well-being also isn't the same question as 'what is it to be a good person?' or 'what is moral righteousness?': compare the difference between being healthy and being a saint. 1

We might think that we already know the answer to this question, even if we can't articulate it right now; and indeed the correct answer couldn't be completely unrecognizable or alien to human experience. But our imagination of what well-being could be is typically too narrow and simple. I make my case for widening and complicating the range of answers we should consider in two stages: I first set out a widely used taxonomy of theories of well-being which picks out some important possibilities, and argue that it is nonetheless inadequate; I then 
offer a different and more expansive way to map the territory, and consider some of the many distinctions and connections among theories and families of theories of well-being it suggests.

\section{Against Parfit's taxonomy}

In Reasons \& Persons, Derek Parfit offered a now-standard taxonomy of theories of well-being

(Parfit 1984: Appendix I, used by Crisp 2006: chapter 4, Crisp 2015; Griffin 1986; Hooker 2000:

\section{§2.3; Hurka 2006; Kagan 1992; Scanlon 1998: chapter 3; Sumner 1996: chapters 3-5, etc.).}

Parfit divides theories of well-being into three main types:

On Hedonistic Theories, what would be best for someone is what would make his life happiest. On Desire-Fulfilment Theories, what would be best for someone is what, throughout his life, would best fulfil his desires. On Objective List Theories, certain things are good or bad for us, whether or not we want to have the good things, or to avoid the bad things.

(Parfit 1984: 493)

All three families have well-known exemplars: hedonists include Jeremy Bentham (1996) and Fred Feldman (2004); desire-fulfilment theorists, Thomas Hobbes (1994) and John $\underline{\text { Rawls (1999: }}$

Part III); objective list theorists, Aristotle (1999) and Martha Nussbaum (2011). But there are three things wrong with Parfit's taxonomy.

First, it is incomplete: it doesn't include all of the major extant theories. For example, it leaves out the Authentic Happiness Theory ( - you are happy if you judge that your life is going well or find it satisfying - and well-being is happiness which is not based on fundamental errors about your life (so someone whose 
happiness is based on falsely believing that her husband adores her does not have well-being, even though she does have happiness). More generally, Parfit's taxonomy leaves out Reflexive Theories (see below), on which well-being is some relation of oneself to oneself or to one's life of satisfaction, endorsement, narration - as the class of which Authentic Happiness is a member.

Second, Parfit's taxa are too broad: they fail to make significant internal distinctions. Hedonism conflates distinct theories of happiness: is it tranquility (Epicurus 1964), a high

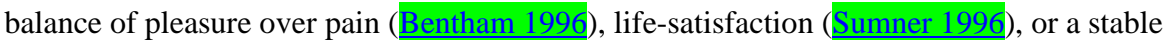
emotional condition ( bin': it is miscellaneous and uninformative, offered only to catch accounts which don't fit into the other two categories. It conflates distinct meanings of 'objective' as not up to its subject, not a mental state, knowable by others, and a proper matter for interference by others (see below for more on these distinctions). It conflates objectivity in all these senses with pluralism, the idea that there are multiple distinct goods. It fails to distinguish explanatory from merely enumerative lists (Crisp 2006: 102-3). 2

Third, Parfit's boundaries are poorly drawn: some significant views are in more than one taxon; some important distinctions cut across taxon-boundaries, making new and potentially interesting groupings and contrasts. On the first point: Parfit himself recognizes the possibility of Composite Theories on which desiring or taking pleasure in goods, and these goods being on the objective list of goods, are both necessary but neither individually sufficient for well-being (defenses of such 'enjoying the good' theories include Adams 1999: chapter 3; Kagan 2009; Wolf 2010). But this possibility mostly gets lost when his taxonomy is wheeled out. John Stuart Mill is usually forced into Hedonism, but his view also has important affinities with Aristotelian 
Objective List theories (Clark 2010, 2012). The second point is my focus in the rest of this chapter.

There are more adequate but less influential attempts at taxonomy in Parfit's style: they add extra taxa, clarify internal distinctions, and move boundaries (for example Haybron 2008: chapter 2; Heathwood 2010; Woodard 2013). But the root of the problem, which these better attempts share, is an assumption that taxa must neatly nest and exclude one another. This biological style of taxonomy is appropriate to the realm of living creatures where speciation derives from selection of random variations in descent. But there's no a priori reason to think that theories speciate by such errors, and when we go and look they turn out not to nest or to exclude in the way that would imply.

I therefore propose that instead of elaborating Parfit-style taxonomies, we should make interesting distinctions among theories and families of theories of well-being, without concern that they should be organized into a cladistic tree diagram, and accepting that they will cross-cut - that there will be multiple boundaries between families of theories, which won't mark out unique territories - and that many of them will be scales not either/or. We should think of these distinctions as usefully various ways of looking, rather than as attempts to cut theory-space at its joints, and should pursue possible combinations, exclusions, and derivations between the contrastive features they pick out.

\section{Better taxonomic distinctions}


In the rest of this chapter I offer some interesting distinctions among (families of) theories of well-being, and consider some of the contrasts, relations, and degrees of freedom or constraint on theorizing which they allow us to see.

\section{Empirical vs. normative theories}

Empirical Theories of well-being pick out something in the world which we can measure, represent, compare across people and across time, and intervene to change. Self-reported lifesatisfaction perhaps works well here (unless such reports turn out to be situational or otherwise unstable: Tiberius \& Plakias 2010), and is certainly widely used in empirical studies of wellbeing and popularizations of their results (e.g. Diener 2009; Layard 2005).

Normative Theories, in contrast, offer something it makes sense to aim at, which is not a completely alien goal and could motivate ordinary human beings: a standard of correctness, or at least a guide, for human action. Life-satisfaction is a poor attempt at this, because it's essentially a by-product (Elster 1983), and aiming directly at it is therefore self-defeating: to gain lifesatisfaction - perhaps to gain happiness on any plausible definition - one needs to have other goals than being satisfied or being happy. More generally: there is no guarantee that what seems best to aim at will be intersubjectively measurable, nor amenable to the kinds of (numerical?) representations and (statistical?) calculations we might like to make, nor such that we can change things to make it easier to get. But this might pull us in the direction of revision rather than description (see below), given our practical interests in such measurement and intervention.

\section{Descriptive vs. revisionary theories}


Descriptive Theories leave everything unchanged, merely regularizing and making explicit what we already thought. They are the typical ambition of analytic philosophy of well-being.

Revisionary Theories come as a surprise, offering to change our lives. They are the ambition of much ancient philosophy, of Buddhist and other religious traditions, and of contemporary self-help books: all hope to reveal that our efforts at well-being have been misdirected because we have misidentified it.

We might have at least two different reasons for revision: either that our current thinking on well-being is unhelpful because it is unable to support our interests in measurement and intervention, as suggested above; or that our thinking on well-being is wrong. In the latter case, perhaps we have been tricked by a corrupt culture into chasing status, wealth, and power, when all we need is a few good friends and enough to eat (Epicurus 1964; Nussbaum 1994). Perhaps that revelation should lead us to abandon our current lives for something very different.

\section{Reflexive vs. non-reflexive theories}

Reflexive Theories make well-being depend on some relation of oneself to oneself or to one's life. Life-satisfaction theories appeal to a relation of positive judgement about or positive feeling about: one has well-being when she judges that her life is going well, or experiences it as satisfying. As noted above, other such theories appeal to other reflexive relations. Narrative Theories, in particular, make well-being depend on having an autobiographical relation of selfnarration to one's own life: one's life goes best, or even has a determinate value at all, only when she tells it as a story which makes sense of it (MacIntyre 1981; Rosati 2013). Not to self- 
narrate is to have a life which is bad for you, because it is fragmentary, incoherent, or meaningless for you.

Non-Reflexive Theories deny this condition: Desire-Fulfilment Theories, for one example, typically say that one's life goes well when what one desires to happen does happen, whatever reflexive relation one has to those desires or to their fulfilment. But some desire-based theories build in a reflexive condition: well-being is the fulfilment not of one's actual desires, but of the desires one would want to have if one were fully rational and informed, that is of

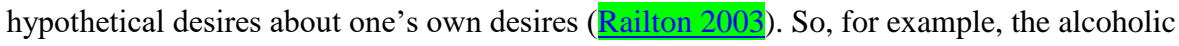
wants a drink, but if she were thinking clearly she would want not to want it, and her life would therefore be made better by not having it.

\section{Compositional vs. additive theories}

The distinction between Compositional Theories and Additive Theories of well-being is about the relation between the goodness of a life as a whole and the goods and bads in that life (pleasures and pains felt, desires fulfilled or unfulfilled, ambitions achieved or thwarted, capacities brought to full expression or stunted, or whatever else one's preferred theory identifies as good and bad). Additive Theories take that relation to be simple addition: to weigh the whole, sum the weights of its parts (putting bad parts on the other side of the scale).

Compositional Theories (Slote 1983; Velleman 2000; Wollheim 1984; I take the term 'compositional' from Brännmark 2001) claim that the overall temporal order, shape, or structure of the life also matters for the goodness of a whole. The standard intuition pump for that conclusion is a comparison between two lives which contain the exact same good and bad parts, 
but in one, the goods are towards the start and the bads towards the end, and in the other, vice versa. So, for example, in one life early success and happiness give way to loss and failure; in the other, hard beginnings of loss and failure are overcome and crowned with late success and happiness. Compositionalists claim that we can see that the second, improving life goes better than the first, declining one.

But why, even if so? What shape or structure is making the difference here? One popular answer is the narrative structure of the life (MacIntyre 1981; Velleman 2000), but that idea is doing different work here than in my discussion of reflexive theories above: there what's important is the relation of self-narration; here, the narrative relations - ironic contrast, aesthetic balance, etc. - of individual goods and bads to one another and to the whole story. Narrative is

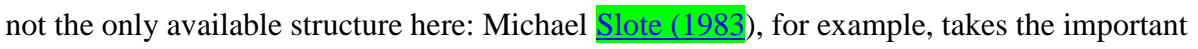
shape of a life to be the biological arc from childhood to 'prime of life' to old age, and argues that goods and bads in the prime of life are far more weighty than in other stages.

\section{Multiple distinctions between subjective and objective}

We should stop using a distinction between subjective and objective theories, because those terms mean too many different things.

Subjective can mean that well-being is a mental state, a quality of experience; that it has no standard of correctness other than first-personal assertion; that it is in some sense a matter of choice for its subject; that no interference by others in one's well-being state is legitimate (and objective then means these claims' respective denials). But these come apart in several ways: belief is a mental state, and has a standard of correctness, the state of the world (my 
grandmother's belief that smoking was good for her asthma was false); seeing something as red is a quality of experience, and has a standard of correctness, what the thing is actually like (my colourblind grandfather often mistook green strawberries for ripe red ones). Plenty of such states - most obviously pain - are not up to their subjects. There's at least no obvious connection between the claim that well-being is a mental state and the claim that a political community should not intervene to change it - consider pain again. However there is a tempting but mistaken tendency to connect epistemic with political authority, which I now examine in more detail.

One subjective/objective distinction is about epistemic authority: well-being's subjectivity or objectivity is about whether well-being is transparent to its subject, in the sense that she knows her own well-being. The limit of transparency is that well-being is first-person incorrigible, like being in pain (there is no illusory pain, and no illusory well-being either), and the limit of non-transparency - call it opacity - is that only others can know my well-being (as though well-being were like a paint spot on my forehead). Many positions on the distribution of epistemic authority between self and others are available between these extremes.

A separate distinction is about political authority: whether what we do about someone's well-being should or should not be up to her. But this is a question about the right, not about the good: about what we should do not what's best. Even if we know the latter, should we maximize good, bring everyone up to a minimum, pursue good only as constrained by rights and duties, or what?

To get from a claim about what's best to a claim about what we should do, we would need to add, first, an account of any other values apart from well-being at stake in the decision; and second, a theory of the relation between the right and the good. For example, direct act 
utilitarianism: well-being is the only intrinsic value; the right action is always the action which maximizes expected intrinsic value. But there is no simple or automatic or theory-free route from the good to the right: no direct way from claims about well-being to claims about what it would be right or rational to do, or about what anyone should or may or must do.

I now want to explore an important application of this general point to the collective case, as when we wonder what our national education or health policy should be. Talk of well-being is sometimes mistakenly understood as troublingly paternalistic or politically perfectionist - as failing to respect liberal constraints on state action, which require neutrality about citizens' conceptions of the good (Rawls 1999; Rawls 2005) ${ }^{3}$ - especially when the talk is of well-being as opaque enough that someone's evaluation of her own well-being can be mistaken.

But the question of the legitimacy of an action or policy is a question about what's right, and as already argued, no account of well-being on its own entails a result about that. It's worth digging more deeply into why there is no such entailment, either in that or in the opposite direction, in the case of political perfectionism.

First, it would be a mistake to deduce the legitimacy or illegitimacy of perfectionist policy directly from any account of well-being, including strongly opaque accounts (in support of perfectionism) or strongly transparent accounts (against it).

Suppose one is trying to legitimate some perfectionist policy with an account of wellbeing on which someone can be wrong about her own well-being: on which first-personal wellbeing judgements are like first-personal health judgements in being opaque and therefore corrigible. Perhaps: I can wrongly think I have lung cancer and be corrected by a doctor who explains my symptoms; I can wrongly think that my life of easy pleasure is good for me and be 
corrected by an Aristotelian philosopher who explains that the life of pleasure is fit for cattle, not humans.

Even from here, to make the move to perfectionist policy we would, first, need to add and defend an account of the right - with what authority do the government house perfectionists act? What rights against them have those they treat as children? Or are these concerns all subordinate to a requirement to maximize the good, as in utilitarianism? Second, we would need either an account of what other values are at stake - individual autonomy, for example - and how they are outweighed; or a defence of the welfarist claim that there are no other intrinsic values ( 1996: chapter 6). Third, we would need an account of how the perfectionist policy succeeds in maximizing value compared to the other policy options. The path from a theory of well-being as opaque to a perfectionist policy about it is, at best, long and winding; that there is such a path at all depends on some highly controversial theoretical claims.

Second, it would equally be a mistake to move from the assumed illegitimacy of political perfectionism to any particular account of well-being - for example, a strongly transparent account on which first-personal well-being judgements are incorrigible, and each of us is the sole and infallible epistemic authority on our own well-being. Perhaps: if you want to find out how well someone's life is going, just ask her - she and no one else really knows.

But in the first place, consider the parallel argument for health: that I ought not to steal your cigarettes doesn't tell us anything about whether cigarettes are bad for your health, or give you authority to decide that question. Political and legal authority are not epistemic authority.

In the second place, such ‘sole and infallible authority' accounts of well-being are false: consider a small child's desire to explore the electrical sockets as an obvious counter-example. If the response is that we're talking about competent adults, then that just further reveals the failure 
of this argument, because the question here is human well-being, not competent adult well-being, and many humans whose lives can go better or worse are not competent adults. Indeed if 'competent adult' means 'someone who is entirely independent, completely knows her own good, and needs no help from others to get it', then no human is a competent adult. Only Epicurean gods could be.

Even an account of well-being which is more plausible than such extreme transparency views, but which still limits others' epistemic authority about my well-being, is not a guarantee against the legitimacy of political perfectionism. Weakness of will is still possible, and one might justify perfectionist policy to keep me doing what I authoritatively judge is for my own good: consider, for example, the aid given to people trying to give up cigarettes by a ban on smoking in public places.

What makes these mistaken moves tempting is an equivocation between epistemic and political authority. Even if we (wrongly) think that each individual has total epistemic authority about her well-being - that is, even if no one could possibly know my well-being better than I do, your well-being better than you do, etc. - it is confused to take that in itself as assigning to each of us sole political authority to manage our own well-being. It might be a pragmatic reason to make that assignment: people often know and care about themselves, and vulnerable things tend to do better in the charge of those who know and care about them. But there are other pragmatic reasons which pull in different directions and which also need to be taken into account: collective action problems, for example.

In the opposite direction, even if we think that each individual has sole political authority to manage and pursue her own well-being, it is confused to take that in itself to reveal anyone's degree of epistemic authority about her well-being, or therefore as constraining our accounts of 
well-being in general. Compare the fact that I do have political authority to manage my own pension (within legal and other constraints), but that I don't know very much - I certainly have far less epistemic authority than a professional financial advisor - about pension fund management. The epistemic and the political come apart here as elsewhere.

An account of well-being is therefore the wrong place to rest political perfectionism or challenges to it, and particular accounts of well-being should neither worry anti-perfectionists nor comfort perfectionists. Subjective/objective is not a useful distinction, but attention to some of the contrasts it conflates allows us to see something about the degrees of freedom between different theories and claims: in particular, to see that our answers to the question, to what extent am I an authority on my own well-being?, leaves open the question of political authority.

There are many other lines of enquiry into relations between different kinds of theory which this non-cladistic perspective opens. For example, and as briefly discussed above, Reflexive Theories and Compositional Theories can be linked by ideas of narrative; and our interests in measurement and intervention may push us in the direction of Revisionary rather than Descriptive Theories.

\section{Concluding summary}

I have argued for an expansion in imagination about what well-being could be, in two stages. I set out and rejected Parfit's influential triad of Hedonist, Desire-Fulfilment, and Objective List Theories of well-being, and further suggested that we shouldn't elaborate Parfit-style cladistic taxonomies, but should instead make multiple, cross-cutting distinctions between (families of) theories of well-being, and consider their interactions. I then put that suggestion into practice by 
distinguishing between Empirical and Normative, Descriptive and Revisionary, Reflexive and Non-Reflexive, and Compositional and Additive Theories, and by breaking up the much-used but incoherent subjective/objective distinction into various distinctions, out of which I focused mostly on questions of Epistemic Authority, Political Authority, and political perfectionism.

I have not argued for or against any particular theory of well-being. My aim has rather been to display some of the wide variety of theories, and of distinctions between theories, available to thinking about well-being.

\section{Notes}

\section{References}

Adams, R. M. 1999. Finite and Infinite Goods: a framework for ethics (Oxford: Oxford University Press).

Aristotle. 1999. Nicomachean Ethics, Terrence Irwin trans. (2nd edn, Indianapolis: Hackett).

Bentham, J. 1996. Introduction to the Principles of Morals and Legislation, J. H. Burns \& H. L.

A. Hart eds. (Oxford: Clarendon Press).

Brännmark, J. 2001. 'Good Lives: Parts and Wholes'. American Philosophical Quarterly 38: $221-231$.

Clark, S. 2010. 'Love, Poetry, and the Good Life: Mill's Autobiography \& Perfectionist Ethics'. Inquiry 53: 565-578.

Clark, S. 2012. 'Pleasure as Self-Discovery'. Ratio 25: 260-276.

Crisp, R. 2006. Reasons and the Good (Oxford: Clarendon Press). 
Crisp, R. 2015. 'Well-Being'. The Stanford Encyclopedia of Philosophy (Summer 2015 edn), Edward N. Zalta ed. http://plato.stanford.edu/archives/sum2015/entries/well-being/ Diener, E. 2009. 'Satisfaction With Life Scale'. http://internal.psychology.illinois.edu/ ediener/SWLS.html (accessed 12 November 15).

Elster, J. 1983. Sour Grapes: studies in the subversion of rationality (Cambridge: Cambridge University Press).

Epicurus. 1964. Letters, Principal Doctrines, and Vatican Sayings, Russel M. Geer trans. (Indianapolis: Bobbs-Merrill).

Feldman, F. 2004. Pleasure and the Good Life: concerning the nature, varieties, and plausibility of hedonism (Oxford: Clarendon Press).

Griffin, J. 1986. Well-Being: its meaning, measurement \& moral importance (Oxford: Clarendon Press).

Haybron, D. M. 2008. The Pursuit of Unhappiness: the elusive psychology of well-being (Oxford: Oxford University Press).

Heathwood, C. 2010. 'Welfare' in The Routledge Companion to Ethics, John Skorupski ed. (London: Routledge): 645-655.

Hobbes, T. 1994. Leviathan, Edwin Curley ed. (Indianapolis: Hackett).

Hooker, B. 2000. Ideal Code, Real World: a rule-consequentialist theory of morality (Oxford: Clarendon Press).

Hurka, T. 2006. 'Value Theory' in The Oxford Handbook of Ethical Theory, David Copp ed. (Oxford: Oxford University Press): 357-379.

Kagan, S. 1992. 'The Limits of Well-Being'. Social Philosophy \& Policy 9: 169-189.

Kagan, S. 2009. 'Well-Being as Enjoying the Good'. Philosophical Perspectives 23: 253-272. 
Layard, R. 2005. Happiness: lessons from a new science (New York: Penguin).

MacIntyre, A. 1981. After Virtue: a study in moral theory (London: Duckworth).

Nussbaum, M. C. 1994. The Therapy of Desire: theory and practice in Hellenistic ethics

(Princeton: Princeton University Press).

Nussbaum, M. C. 2011. Creating Capabilities: the human development approach (Cambridge, MA: Belknap).

Parfit, D. 1984. Reasons and Persons (Oxford: Clarendon Press).

Railton, P. 2003. 'Moral Realism' in Facts, Values, and Norms: essays towards a morality of consequence (Cambridge: Cambridge University Press): 3-42.

Rawls, J. 1999. A Theory of Justice (revised edn, Oxford: Oxford University Press).

Rawls, J. 2005. Political Liberalism (expanded edn, New York: Columbia University Press).

Raz, J. 1986. The Morality of Freedom (Oxford: Clarendon Press).

Rosati, C. 2013. 'The Story of a Life'. Social Philosophy and Policy 30: 21-50.

Scanlon, T. M. 1998. What We Owe to Each Other (Cambridge, MA: Harvard University Press).

Slote, M. 1983. Goods and Virtues (Oxford: Clarendon Press).

Sontag, S. 1991. Illness as Metaphor and AIDS and Its Metaphors (London: Penguin).

Sumner, L. W. 1996. Welfare, Happiness, \& Ethics (Oxford: Oxford University Press).

Taylor, C. 1989. Sources of the Self: the making of the modern identity (Cambridge, MA:

Harvard University Press).

Commented [AuQ1]: Please indicate where the in-text citation for [[Taylor, C. 1989]] should appear in the text.

Velleman, J. D. 2000. 'Well-Being and Time' in The Possibility of Practical Reason (Oxford:

Oxford University Press): 56-84. 
Wall, S. 2012. 'Perfectionism in Moral and Political Philosophy'. The Stanford Encyclopedia of Philosophy (Winter 2012 edn), Edward N. Zalta ed. http://plato.stanford.edu/archives/win2012/entries/perfectionism-moral/

Wolf, S., Macedo, S., Koethe, J., Adams, R. M., Arpaly, N., and Haidt, J.tet at. 2010. Meaning in Commented [AuQ3]: AU: Please provide names of all Life and Why it Matters (Princeton: Princeton University Press)

Wollheim, R. 1984. The Thread of Life (Cambridge, MA: Harvard University Press).

Woodard, C. 2013. 'Classifying Theories of Welfare'. Philosophical Studies 165: 787-803.

1 We have a tendency to confuse ill health with lack of righteousness - Sontag (1991) - which suggests that we should be particularly careful to mark this distinction.

Parfit says much more about the internal distinctions of the desire-fulfilment taxon. I don't have space here to follow him through these complexities, but they don't refute my general point.

This is actually too simple, because there are perfectionist as well as neutralist liberals (e.g.

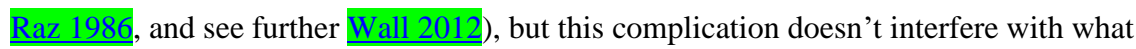
follows. 